\title{
Molecular size of riverine dissolved organic matter influences coastal phytoplankton communities
}

\author{
Tony Fagerberg*, Therese Jephson, Per Carlsson
}

Department of Limnology and Marine ecology, Lund University/Campus Helsingborg, PO Box 88225108 Helsingborg, Sweden

\begin{abstract}
Dissolved organic matter (DOM) concentrations in many northern European freshwater systems have been increasing during the past decades. DOM affects the marine plankton community where rivers discharge into the sea. Large DOM molecules have been suggested to be more available to aquatic plankton than smaller ones due to their more recent origin in the degradation process. In this study, we investigated the effect of riverine DOM molecular size on coastal plankton with the hypothesis that nitrogen associated with large molecules stimulates the plankton more than nitrogen in smaller molecules. Three size fractions of riverine DOM were isolated with tangential ultrafiltration and introduced at similar nitrogen concentrations to mesocosms with a natural coastal marine plankton community under nitrogen limiting conditions. The results show that growth of bacteria and dinoflagellates, but not diatoms, was stimulated by addition of large DOM molecules. Even though organic nitrogen concentrations tended to decrease more in large DOM treatments compared to smaller DOM treatments, no significant differences were detected. However, proteolytic enzyme activities were elevated in treatments with the largest DOM molecules, suggesting that more organic nitrogen was utilized in this treatment. We suggest that input of larger river DOM molecules to nitrogen limited coastal systems may influence the composition of the coastal phytoplankton community in favour of dinoflagellates.
\end{abstract}

KEY WORDS: Dissolved organic matter $\cdot$ DOM $\cdot$ River $\cdot$ DON $\cdot$ Molecular size $\cdot$ Marine phytoplankton

\section{INTRODUCTION}

Increasing concentrations of dissolved organic matter (DOM) have been reported from northern European freshwater systems (Hongve et al. 2004, Vuorenmaa et al. 2006, Erlandsson et al. 2008). The mechanisms responsible for this aquatic 'organification' has not been completely identified, but large scale processes such as reduced soil acidity (Evans et al. 2007) and/or climate change and altered hydrological conditions (Freeman et al. 2001, Hejzlar et al. 2003) have been proposed to be involved.

The DOM in lakes and streams is eventually discharged into coastal waters, where it can have profound effects on the cycling of nutrients and the configuration of coastal marine food webs (e.g. Carlsson et al. 1995, 1998, See et al. 2006). River DOM may also regulate the initiation and persistence of coastal algal blooms (Boyer et al. 2006) as well as influence the composition of the marine phytoplankton community (e.g. Granéli \& Moreira 1990).

Most of the river DOM is produced by biotic and abiotic degradation of dead plant and animal material. Continuous weathering degrades particulate organic matter until it is considered dissolved in the water (usually defined as molecules that pass through a $0.2 \mu \mathrm{m}$ filter). The organic molecules are continually being broken down even after they are dissolved, resulting in a size spectrum of DOM ranging from large colloids to small completely dissolved molecules. DOM bioavailability has been suggested to be influenced by its molecular size. Amon \& Benner (1996) developed a conceptual model of DOM bioreactivity, in which large molecules are considered more available for biodegradation. This DOM size-reactivity continuum model was attributed to a more recent origin of 
large molecules in the general DOM degradation process and was based on experiments with bacteria and DOM from freshwater, estuarine and marine environments. The concept has been supported by other studies (e.g. Tulonen et al. 1992, Fagerberg et al. 2009).

Intense rainfall over land gives rise to high river discharge that can increase concentrations of riverine organic matter (e.g. Buffam et al. 2001), and thus export a pulse of DOM associated nutrients to the coast. A large proportion of these nutrients, especially dissolved organic nitrogen (DON), have been shown to be available to estuarine bacteria (e.g. Seitzinger et al. 2002). Interestingly, some phytoplankton species may also make use of organic nitrogen, either by employing proteolytic enzymes (e.g. Dyhrman 2005), and/or by directly ingesting nitrogen rich proteins via endocytosis (e.g. Klut et al. 1987).

In the coastal environment, nitrogen is often limiting primary production. This is especially true during summer when concentrations of easily accessible dissolved inorganic nitrogen (DIN; nitrate, nitrite and ammonium) are low (Granéli \& Moreira 1990). Under such conditions, organic nitrogen would be beneficial to those organisms that are able to use it (Butler et al. 1979). In addition, trace metals may also limit plankton growth in some parts of the ocean, and some phytoplankton can be released from iron limitation by additions of DOM associated iron (Stolte et al. 2006).

In this study, we test if the river DOM-size reactivity concept proposed by Amon \& Benner (1996) is applicable to coastal phytoplankton. The primary aim was to investigate whether the DOM associated nitrogen stimulates more plankton growth in large DOM size fractions than in smaller size fractions. To address these questions, we designed a mesocosm experiment with a natural community of coastal plankton on the west coast of Sweden. Using tangential ultrafiltration, 3 size fractions of riverine DOM were isolated and introduced to the mesocosms in similar nitrogen concentrations under nitrogen limiting conditions.

\section{MATERIALS AND METHODS}

Isolation of DOM. In July 2007 after a period of intense rainfall, 3 different size fractions of DOM were isolated from river Fylleån. The river discharge was kindly provided by the Swedish Meteorological and Hydrological Institute that conducts daily measurements on river water transport in Swedish rivers and streams. Discharge of river Fylleån at the time of sampling was $\sim 3$ times higher $\left(22.1 \mathrm{~m}^{3} \mathrm{~s}^{-1}\right)$ than the 2007 summer average $\left(6.7 \mathrm{~m}^{3} \mathrm{~s}^{-1}\right)$. This river empties into Laholm Bay on the west coast of Sweden. Its drainage area is mainly dominated by coniferous forest (Carls- son et al. 1998), and its dissolved organic carbon (DOC) concentrations are normally between 10 to $14 \mathrm{mg} \mathrm{l}^{-1}$ (Kullberg \& Petersen 1987). A 5001 polyethylene container that had been thoroughly washed and rinsed with Milli-Q water was used to collect the river water, which was visibly brown presumably due to high concentrations of DOM. The water was immediately filtered though a $30 \mu \mathrm{m}$ nylon sieve to remove leaves and large debris, and transported to a refrigerated laboratory $\left(8^{\circ} \mathrm{C}\right)$. There, the water was filtered under low pressure through $1.2 \mu \mathrm{m}$ filter capsules, followed by sterile filtering through a $0.2 \mu \mathrm{m}$ filter cartridge (Gelman supor). The $1.2 \mu \mathrm{m}$ filter was used to remove large particles that would otherwise rapidly have clogged the $0.2 \mu \mathrm{m}$ filter. The sterile-filtered water was collected in several acid washed and Milli-Q water rinsed, 251 , polyethylene containers. These containers were then transported to a $4^{\circ} \mathrm{C}$ thermo-constant room where the river water was concentrated 50 times using tangential ultrafiltration. Three ultrafilter cartridges (Prep-Scale/TFF cartridge, Millipore) were used with molecular weight (MW) cut-off sizes of 100, 10 and $1 \mathrm{kDa}$, respectively. Before use, the ultrafilters were cleaned with $0.1 \mathrm{M} \mathrm{NaOH}$ and rinsed with Milli-Q water according to the manufacturer's recommendations. The ultrafiltration process resulted in 3 size fractions of river DOM molecules: $0.2 \mu \mathrm{m}$ to $100 \mathrm{kDa}$ (large, LDOM), 100 to $10 \mathrm{kDa}$ (medium, MDOM), 10 to $1 \mathrm{kDa}$ (small, SDOM).

Experiment setup. The experiment was carried out on the west coast of Sweden at Sven Lovén Center for Marine Sciences in August of 2007. Twenty-four food grade polyethylene containers $(50$ l) previously washed and rinsed with both Milli-Q water and seawater were placed in an outdoor pool circulated with ambient seawater. A natural coastal plankton community was collected from the fjord at $3 \mathrm{~m}$ depth with a peristaltic pump. The containers were filled to $40 \mathrm{l}$ and care was taken to distribute the water evenly among the containers over time. These mesocosms were then left undisturbed for $24 \mathrm{~h}$ for acclimatization. The following day, we divided the mesocosms into controls (no DOM additions) and treatments with 4 replicates each. Treatments were as follows: $+7 \mu \mathrm{M}$ nitrate $+30 \mathrm{nM}$ iron (from an F/2 metal solution; Guillard \& Ryther 1962) + L-, M- and SDOM. DOM was added to increase the organic nitrogen concentrations in each DOM treatment with $7 \mu \mathrm{M}$ (see Table 1). These nitrogen concentrations are within the natural range reported for marine estuaries and coastal waters (Berman \& Bronk 2003). Nitrate was chosen as an inorganic nitrogen treatment since it often dominates DIN in stream water and is used as a nitrogen source by most phytoplankton. The trace metal treatment was included in the experiment since DOM associated metals has been shown to stimulate 
coastal plankton growth (Stolte et al. 2006). F/2 trace metal solution was used since it is commonly used in marine phytoplankton culturing, and thus, composed to ensure that their trace metals requirements are fulfilled. All containers received $3 \mu \mathrm{M}$ phosphate to ensure that this nutrient would not limit growth in the algal community. This concentration is somewhat higher than natural phosphate concentrations in estuaries elsewhere (Dafner et al. 2007), but still within the range of summertime. The experiment was considered initiated when all nutrients had been added. Samples were immediately collected for analysis of dissolved organic and inorganic nutrients, peptidase activity, phytoplankton and bacteria abundance. Samples for these analyses were also collected every other day for $11 \mathrm{~d}$. This time period was chosen since previous experiments have shown that it is long enough to detect the effect of the added nutrients on the plankton (e.g. Carlsson et al. 1995), and short enough to prevent a biofilm of e.g. bentic diatoms to significantly appear on the walls of the mesocosms that may interfere with the plankton-nutrient dynamics (Chen et al. 1997).

Since high concentrations of river DOM can have negative impacts on photosynthesizing plankton due to its light absorbing nature (e.g. Carpenter et al. 1998), we measured initial light intensities in all containers after DOM additions using a Li-Cor 4000 data logger.

Phytoplankton and bacteria counting. Phytoplankton samples (200 ml) were fixed with GF/F filtered acid Lugol's solution ( $1 \% \mathrm{v} / \mathrm{v}$ final concentration) and counted in $10 \mathrm{ml}$ Utermöhl chambers under an Olympus CKX41177 inverted microscope. The samples were analyzed in transects at 200x magnifications, and at least 100 , but often $>200$, individual cells were counted. We also measured the geometry of 10 to 20 cells of each species per group of species per sample to calculate their biovolume. Biovolume was converted into biomass (carbon) according to Carlsson et al. (1995).

Bacteria were counted using a modified epifluorescence microscoping technique (Porter \& Feig 1980). Samples $(1.5 \mathrm{ml})$ were fixed with $\mathrm{GF} / \mathrm{F}$ filtered formaldehyde $(2 \% \mathrm{v} / \mathrm{v})$. A DNA-specific fluorochrome SYTOX (Molecular probes) dissolved in $5 \mathrm{mM}$ dimethylsulfoxide (DMSO, $1.5 \mu \mathrm{M}$ final concentration) was introduced into $1 \mathrm{ml}$ of the bacteria sample. These samples were then filtered onto $0.2 \mu \mathrm{m}$ black polycarbonate filters (Poretics). The stained bacteria were enumerated under an Olympus BX60 epifluorescence microscope (excitation filter: 450 to $480 \mathrm{~nm}$, beamsplitter: $500 \mathrm{~nm}$, barrier filter: $>515 \mathrm{~nm}$ ). At least 300 bacteria were counted in each sample (e.g. Boyer et al. 2006)

Nutrients. A total of $100 \mathrm{ml}$ water sample was filtered through a GF/F-filter that had been thoroughly rinsed with Milli-Q water. The first $50 \mathrm{ml}$ were discarded and the remaining $50 \mathrm{ml}$ sample was collected and stored at $-20^{\circ} \mathrm{C}$ until analyses of total dissolved nitrogen (TDN), nitrate + nitrite, ammonium and phosphate. DON was calculated as the difference between TDN and DIN (nitrate + nitrite + ammonium). All nutrients were analyzed in a Technicon TRAACS 800 Autoanalyzer with detection limits of $0.3,0.02,0.02$ and $0.8 \mu \mathrm{M}$ for ammonium, nitrate/nitrite, phosphate and TDN, respectively. Dissolved organic carbon (DOC) was analysed in a Shimadzu TOC-V CN analyser at Lund University

Leucine aminopeptidase (LAP). LAP activity was measured in each of the experimental containers by adding the substrate L-leucine 7-amino 4-methylcoumarine (SIGMA) to $1 \mathrm{ml}$ subsamples. When aminopeptidase degrades this substrate, a fluorescent product 7-amino 4-methylcoumarine (AMC) is produced (Hoppe 1983). The substrate was dissolved in 2methoxyethanol to a final substrate concentration of 2 $\mathrm{mM}$ and stored at $-20^{\circ} \mathrm{C}$ until use. A final concentration of $50 \mu \mathrm{M}$ substrate was added to each sub-sample. The production rate of the fluorescent product was determined over a $1 \mathrm{~h}$ incubation period in a Viktor 1420 multicounter, with excitation and emission filters of 380 and $578 \mathrm{~nm}$, respectively. Increase in fluorescence as a result of enzyme degradation of the substrate was converted into LAP activity after calibrating against a standard curve with known concentrations of the degradation product (AMC, Sigma). Enzymatic activity is expressed as nmol AMC $\mathrm{l}^{-1} \mathrm{~h}^{-1}$. Analyzed together with the samples were 2 substrate controls with sterile filtered $(0.2 \mu \mathrm{m})$ and autoclaved seawater + substrate (final concentration of $50 \mu \mathrm{M}$ ). Fluorescence did not increase in any of these controls, confirming that the substrate was uncontaminated.

Statistical analysis. Data from the experiment were analysed statistically in SPSS 14.0. We used 1-way analysis of variance (ANOVA), or repeated measure ANOVA (RM-ANOVA), with Tukey's post-hoc test, where mentioned, to detect differences among treatments. Data were checked for either homogeneity of variances with Levene's test or normal distribution with Kolmogorov-Smirnov test before analysis. Logtransformation of data was made prior to the parametric tests when necessary.

\section{RESULTS}

\section{Light}

Light intensities in the centre of the containers varied between 160 and $199 \mu \mathrm{E} \mathrm{m} \mathrm{m}^{-2} \mathrm{~s}^{-1}$, which corresponded to an estuarine depth of 1 to $2 \mathrm{~m}$. Although these intensities were high enough to support growth of the plankton, some dinoflagellate species have been 
observed to be photoinhibited at these intensities (cf. Richardson et al. 1983). Considering that dinoflagellates are among the most light sensitive phytoplankton groups (Richardson et al. 1983), but still grew well in the nitrate and DOM treatment, photoinhibition was not likely a factor in the present experiment. There was no differences in light intensities between the DOM treatments and the control ( $\mathrm{p}=0.06$, ANOVA). The low $p$-value is a result of higher light intensities measured in the largest DOM fraction. However, since the concentrate of this fraction was visibly darker than the other DOM concentrates, this trend was not likely caused by the DOM. Instead, rapid changes in ambient light conditions may have resulted in the observed trend since it was impossible to measure all containers simultaneously with the Li-Cor data logger.

\section{Phytoplankton}

The initial phytoplankton community was composed primarily of small dinoflagellates and diatoms. Small dinoflagellates were dominated by species of the group Gymnodiniales, and were pooled into 1 group defined by a cell diameter $<30 \mu \mathrm{m}$. The diatoms, dominated by small species (e.g. Leptocylindrus minimus and Cylindrothecae closterium), were grouped as small diatoms. Large species from each group were not included in this study since their cell numbers were low throughout the experiment. Initial cell concentrations did not differ among any of the treatments for either phytoplankton group (dinoflagellates: $p=0.50$, diatoms: $p=0.14$, ANOVA). A much larger increase in phytoplankton biomass was detected in the nitrate treatments than in the trace metal treatment compared to the controls (Fig. 1), confirming that nitrogen was the growth limiting nutrient for the phytoplankton in
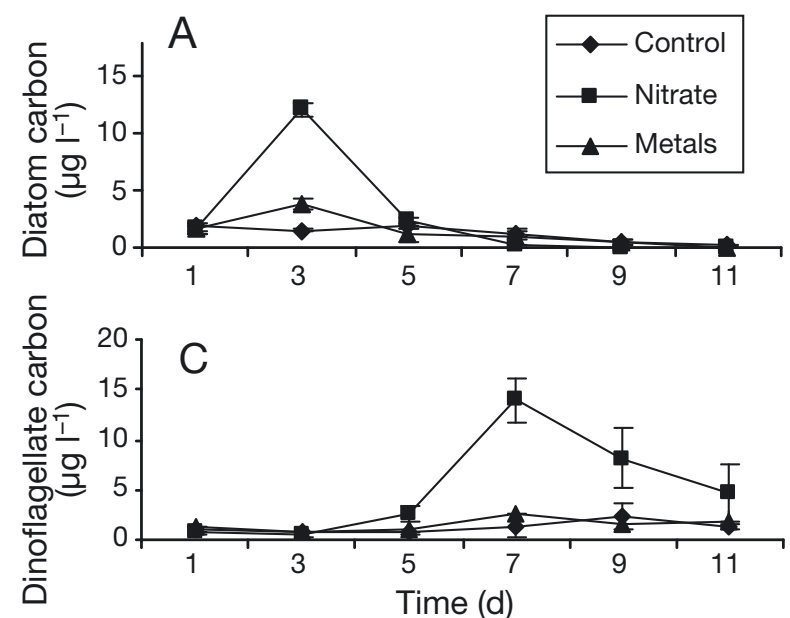

the mesocosms. Diatom biomass increased rapidly between Days 1 and 3 in the nitrate treatment, but this trend was not observed in the DOM treatments. Instead, growth was less intense and prolonged until Day 5 to 7, after which their biomass declined. Dinoflagellate biomass on the other hand, did not change much during the first days of the experiment, but started to increase in the nitrate and DOM treatments after Day 3 to 5. The dinoflagellates did not peak until Day 7 , suggesting that this group was not able to respond as rapidly to the nitrate and DOM treatments as the diatoms. DOM additions stimulated both dinoflagellates and diatoms compared to controls (Fig. 1), but only the dinoflagellates responded to DOM size. Significantly more dinoflagellate biomass was produced in the largest size fraction (LDOM) than in the smaller DOM fractions (MDOM, SDOM) ( $\mathrm{p}<0.01$, RMANOVA, Tukey's HSD). Dinoflagellates also seemed to be more stimulated by MDOM than by SDOM, but this was not significant. ( $\mathrm{p}=0.17$, RM-ANOVA, Tukey's HSD). DOM size had no effects on diatom biomass over the experiment ( $p=0.206$, RM-ANOVA).

\section{Bacteria}

The initial bacterial concentrations in the mesocosms were $0.25 \times 10^{6}$ cells $\mathrm{ml}^{-1}$, and differed among the treatments only due to marginally lower concentrations in the controls ( $p<0.05$ ANOVA). Over the experiment, bacteria numbers were significantly higher in LDOM treatment than in the 2 smaller DOM treatments $(\mathrm{p}<$ 0.01, RM-ANOVA, Tukey's HSD; Fig. 2). As with dinoflagellates, a trend suggesting higher bacterial numbers in MDOM compared to SDOM can be seen in Fig. 2, but this was not significant ( $p=0.67$, RMANOVA, Tukey's HSD). Bacterial concentrations were
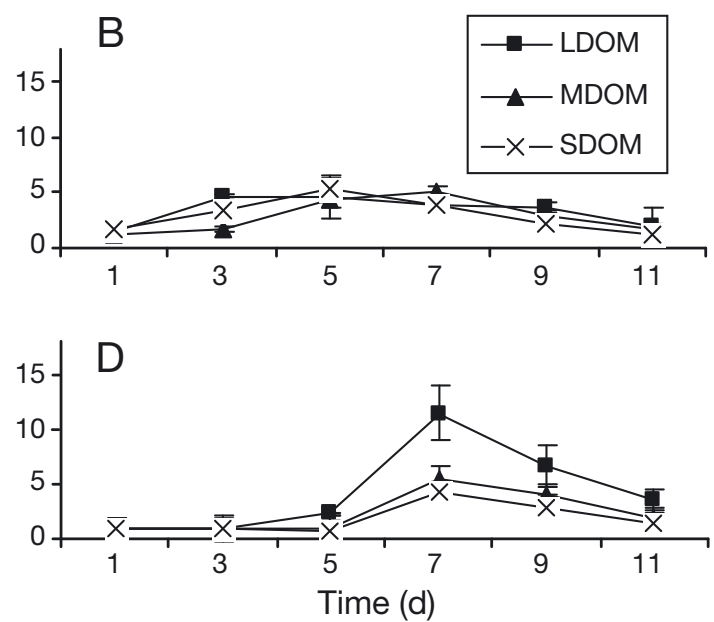

Fig. 1. Diatom and dinoflagellate biomass shown as $\mu \mathrm{g}$ carbon $\mathrm{l}^{-1}$ (mean $\left.\pm \mathrm{SD}, \mathrm{n}=4\right)$ for $(\mathrm{A}, \mathrm{C})$ controls (no addition), nitrate, trace metals, and (B,D) DOM treatments. DOM: dissolved organic matter; LDOM: DOM >100 kDa; MDOM: 100 to $10 \mathrm{kDa}$; SDOM: 10 to $1 \mathrm{kDa}$ 

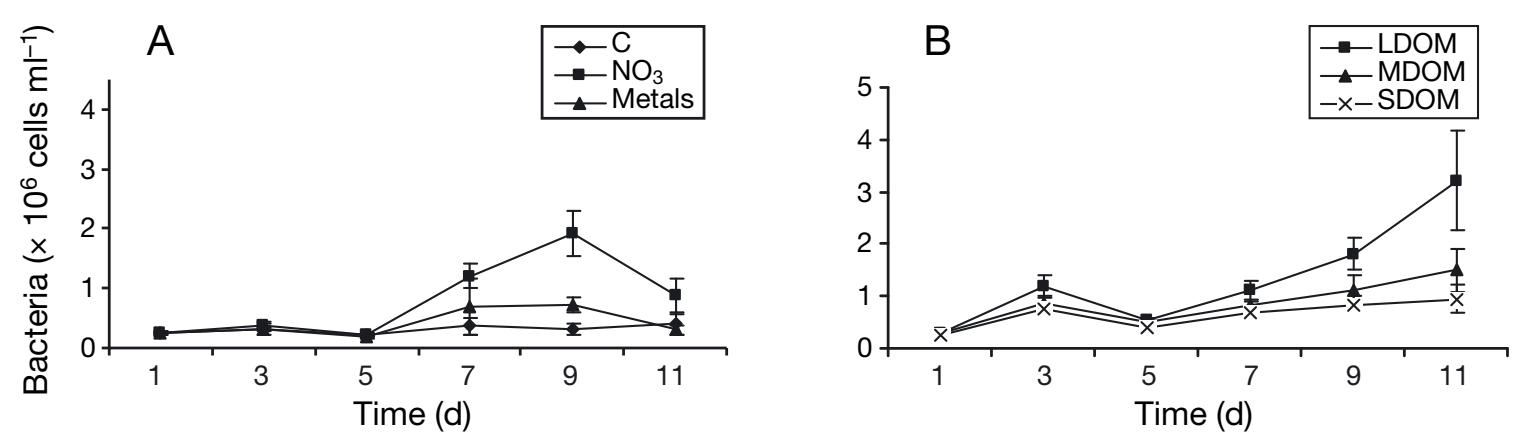

Fig. 2. Bacteria cell concentrations in cells $\mathrm{ml}^{-1} \times 10^{6}($ mean $\pm \mathrm{SD}, \mathrm{n}=4)$. Treatments as in Fig. 1

very low in the controls and did not change much over the experiment, while concentrations in the nitrate treatment were higher than in both controls and the trace metal treatment ( $\mathrm{p}<0.01, \mathrm{RM}-\mathrm{ANOVA}$, Tukey's HSD). Contrary to the DOM treatments where bacteria did not reach maximum cell densities, cell numbers peaked on Day 9 in both the trace metal and nitrate treatments. On this day, bacteria concentrations were $\sim 2.5$ times higher in the nitrate treatment compared to the trace metal treatment, indicating again that nitrogen was the more important element in stimulating plankton growth.

\section{Nutrients}

DIN concentrations in the mesocosms were low at the beginning of the experiment (Table 1), and there were no differences among the treatments when the nitrate treatment was excluded ( $p=0.16$, ANOVA). This shows that the addition of DOM did not significantly increase the DIN concentrations. No differences in DON concentrations were detected initially among the DOM treatments ( $p=0.53$, ANOVA) (Table 1). Based on known concentrations in the isolated DOM (Table 2), the additions increased the DOC concentrations in the mesocosms by $245.4 \pm 3.4,226.3 \pm 3$, and $299.9 \pm 2.8 \mu \mathrm{M}$ in LDOM, MDOM and SDOM treatments, respectively

Table 1. Dissolved inorganic nitrogen (DIN), phosphorus (DIP), and dissolved organic nitrogen (DON) concentrations (mean $\pm \mathrm{SD}, \mathrm{n}=3$ ) measured in the mesocosms immediately after nutrient additions. Large (L) and medium (M) molecule size fraction of dissolved organic matter (DOM)

\begin{tabular}{|lccc|}
\hline Treatment & DIN $(\mu \mathrm{M})$ & $\mathrm{DIP}(\mu \mathrm{M})$ & $\mathrm{DON}(\mu \mathrm{M})$ \\
\hline No additions & $1.9 \pm 0.3$ & $3.8 \pm 0.2$ & $15.3 \pm 0.8$ \\
Nitrate & $7.4 \pm 0.5$ & $3.3 \pm 0.3$ & $16.7 \pm 1.0$ \\
Trace metals & $1.6 \pm 0.3$ & $3.6 \pm 0.1$ & $16.3 \pm 0.7$ \\
LDOM & $2.4 \pm 0.3$ & $3.3 \pm 0.3$ & $22.7 \pm 1.8$ \\
MDOM & $2.3 \pm 0.2$ & $3.5 \pm 0.2$ & $21.8 \pm 0.8$ \\
DOM & $2.3 \pm 0.6$ & $3.5 \pm 0.1$ & $22.0 \pm 0.3$ \\
\hline
\end{tabular}

(mean $\pm \mathrm{SD}$ ). Phosphate concentrations differed little among the treatments on Day 1 (Table 1), and did not change much over the experiment except for a minor decrease in the DOM treatments. Most of the added nitrate was consumed in the nitrate treatment before Day 7 , and small amounts of DIN were used in the other treatments. DON concentrations in the controls (no DOM added) increased over the experiment, indicating that the DON from the seawater was not used to any larger extent by the plankton. DON tended to decrease more in the LDOM treatment compared to the other 2 DOM-size treatments (SDOM and MDOM) between Day 1 and 7 (Fig. 3A), and a similar pattern was observed between Day 1 and 11, except for a more pronounced decrease in MDOM-DON (Fig. 3B). However, no significant differences in DON decrease were found either between Day 1 and 7 ( $p=0.07$, ANOVA), or between Day 1 and 11 ( $\mathrm{p}=0.12$, ANOVA).

\section{Leucine aminopeptidase (LAP)}

No differences in LAP activity were found among treatments on Day 1 ( $\mathrm{p}=0.08$, ANOVA, Tukey's HSD) (Fig. 4). LAP activity in all treatments increased by Day 3. Similar to the bacterial concentrations, LAP activity was then reduced in all treatments between Day 3 and 5, followed by yet another increase. Activi-

Table 2. Dissolved organic carbon (DOC), nitrogen (DON), and $\mathrm{C}: \mathrm{N}$ ratios (mean $\pm \mathrm{SD}, \mathrm{n}=3$ ) from 3 ultrafiltrated dissolved organic matter (DOM) size concentrates (L: large, M: medium, S: small)

\begin{tabular}{|cccc|}
\hline $\begin{array}{c}\text { DOM size } \\
(\mathrm{kDa})\end{array}$ & $\begin{array}{c}\text { DOC } \\
(\mu \mathrm{M})\end{array}$ & $\begin{array}{c}\text { DON } \\
(\mu \mathrm{M})\end{array}$ & DOC:DON \\
\hline $\begin{array}{c}\text { LDOM } \\
(>100)\end{array}$ & $14764 \pm 202$ & $605 \pm 54$ & $24.5 \pm 2.5$ \\
$\begin{array}{c}\text { MDOM } \\
(100 \text { to } 10)\end{array}$ & $10204 \pm 136$ & $453 \pm 43$ & $22.6 \pm 2.4$ \\
$\begin{array}{l}\text { SDOM } \\
(10 \text { to } 1)\end{array}$ & $16279 \pm 152$ & $543 \pm 11$ & $30.0 \pm 0.3$ \\
\hline
\end{tabular}



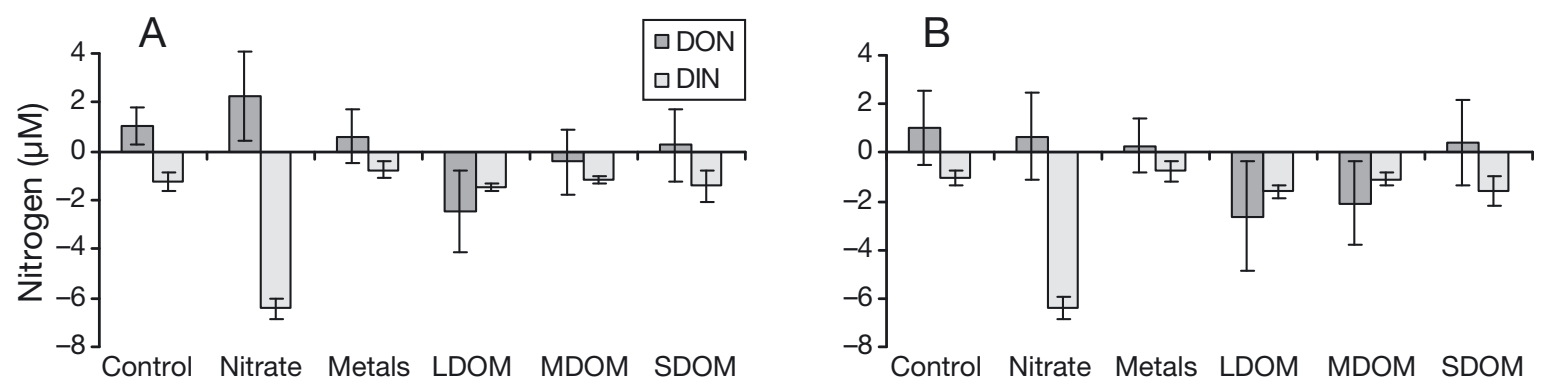

Fig. 3. Changes in dissolved organic (DON) and inorganic (DIN) nitrogen (mean $\pm S D, n=4)$ between (A) Day 1 and 7 , and (B) 1 and 11. Positive and negative values correspond to net increase and decrease in nitrogen concentrations. Treatments as in Fig. 1
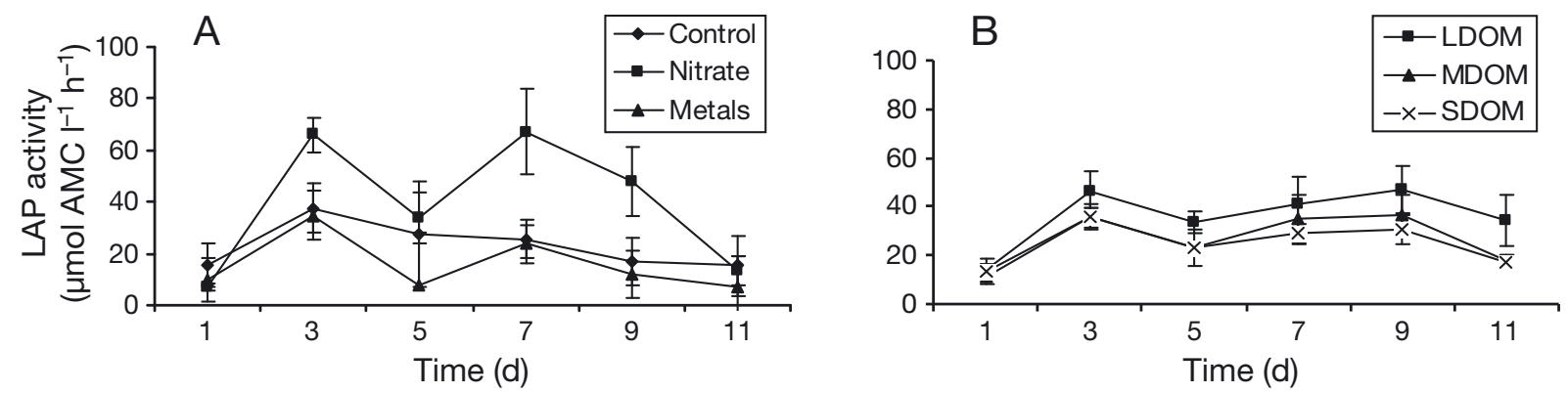

Fig. 4. Leucine aminopeptidase (LAP) activity (mean $\pm \mathrm{SD}, \mathrm{n}=4$ ). Treatments as in Fig. 1

ties were higher in the LDOM treatment than in the smaller DOM size fractions $(\mathrm{p}<0.05, \mathrm{RM}-\mathrm{ANOVA}$, Tukey's HSD), but there was no difference between MDOM and SDOM ( $\mathrm{p}=0.89$, RM-ANOVA, Tukey's HSD) (Fig. 4B). Activities in the nitrate treatment exceeded those in the metal treatment and controls ( $p<0.05$, RM-ANOVA, Tukey's HSD), but there were no significant differences between the latter 2 treatments over the experiment ( $\mathrm{p}=0.45$, RM-ANOVA, Tukey's HSD) (Fig. 4A).

\section{DISCUSSION}

This study shows that riverine DOM can stimulate growth of marine primary producers and bacteria, and that DOM size can have a profound influence on coastal dinoflagellates and bacteria in a nitrogen limited environment. In contrast, DOM size did not affect the diatoms, suggesting that DOM size may also influence the structure of coastal phytoplankton communities. River DOM has earlier been shown to enhance growth in aquatic plankton (Tulonen et al. 1992, Carlsson et al. 1995), and DOM molecular size has been put forward as a factor influencing its stimulatory effect. For example, Tulonen et al. (1992) observed an increased biomass production in a freshwater flagellate when incubated with large DOM molecules. The same relationship has also been observed for aquatic bacte- ria (Tulonen et al. 1992, Amon \& Benner 1996). Amon \& Benner (1996) attributed this trend to a more recent origin of large molecules in the DOM degradation process, and postulated a DOM-size reactivity concept in which large molecules are more prone to biodegration. Based on the results from the present study, we suggest that this concept may also be applicable to natural communities of marine dinoflagellates and bacteria. In support of this, Fagerberg et al. (2009) recently showed that growth in the toxic marine dinoflagellate Alexandrium minutum was more enhanced by addition of large river DOM molecules compared to smaller ones.

The present experiment was conducted under nitrogen limiting conditions with the hypothesis that the organic nitrogen added with the riverine DOM would stimulate growth in those species, or groups of species that could utilize it. It is known, however, that DOM can also stimulate plankton growth by contributing trace metals. For example, Stolte et al. (2006) showed that some coastal phytoplankton species may be released from iron limitation by adding DOM from humic rich rivers. In the present study, additions of trace metals only resulted in a small increase in phytoplankton growth compared to when nitrate was added. We therefore suggest that most of the observed increase in phytoplankton biomass and bacterial numbers was caused by an increase in nitrogen availability in this experiment. 
DOM was added to the mesocosms to ensure that the 3 DOM treatments received similar organic nitrogen concentrations. This resulted in different amounts of DOC added between treatments. These differences were rather small between the LDOM and MDOM treatments, while the SDOM treatment received higher concentrations. Since the plankton grew comparably slow with SDOM, we suggest that the extra DOC added was of little importance for both bacteria and phytoplankton growth in this experiment. In fact, the relative high $\mathrm{C}: \mathrm{N}$ ratio of the SDOM can be an indication of lower bioavailability of this DOM (cf. Wiegner \& Seitzinger 2004).

Most of the natural DOM is composed of high molecular weight compounds and must therefore be processed, e.g. by catabolic enzymes, before it can be utilized (Chróst 1991). Leucine aminopeptidase degrades large organic molecules carrying amino groups (e.g. proteinaceous material, peptides etc.) into amino acids. Free amino acids can be easily taken up by both bacteria and several phytoplankton species (see Berman \& Bronk 2003 for review). We observed higher LAP activities in the LDOM treatment compared to those in the 2 smaller DOM size treatments. It is thus likely that the more easily utilizable nitrogenous compounds were released from the largest DOM size fraction and subsequently utilized by the plankton. The high LAP activities in the nitrate treatment is confounding, but may have been the result of the relative higher numbers of plankton cells in this treatment due to the growth stimulating nitrate. The LAP activities reported here are within the range of those that have been found in coastal waters elsewhere (Gaas \& Ammerman 2007).

Bacteria are well known decomposers of DOM and employ an array of enzymes for this purpose, including aminopeptidases (e.g. Azúa et al. 2003). Thus, the increased growth of bacteria and dinoflagellates in the LDOM treatment may have been made possible by the ability of bacteria to scavenge organic nitrogen from the added DOM in this way. Mixotrophy (complementing photosynthesis with heterotrophy) is widespread among dinoflagellates (Stoecker 1999), and nutrients may thus have been gained by consumption of other species. It is also possible that nutrients were released via the microbial loop (Azam et al. 1983), in which nutrients taken up by bacteria can be made available to phytoplankton via heterotrophic flagellate or ciliate bacterivory. Experiments with bacteria free cultures have shown that dinoflagellate growth can be enhanced when inoculated with sterile river DOM (Carlsson et al. 1998). It is also established that several dinoflagellate species possess surface-bound aminopeptidases (Stoecker \& Gustafson 2003, Dyhrman 2005, Salerno \& Stoecker 2009). Some dinoflagellates also seem to have the ability to actively ingest large proteins and DOM molecules, possibly via pinocytosis (Klut et al. 1987, Legrand \& Carlsson 1998), and may make use of nitrogen in this way. Hence, dinoflagellates may utilize DOM-associated nitrogen without depending on bacteria, and thus, actively compete with them for this resource.

When comparing the growth patterns of dinoflagellates and bacteria in the LDOM treatment with the nitrate treatment (Figs. 1 \& 2), it is apparent that the added nitrogen had a positive influence on both these plankton groups. However, despite the low detection limits for TDN and inorganic nitrogen analysis, variations in the dataset were too high for the statistical analysis to detect any differences in DON decrease between the DOM treatments over the experiment. Nevertheless, there was a tendency towards a more pronounced DON decrease in the LDOM treatment between Day 1 and 7 (Fig. 3). This corresponds with the observed higher biomass of dinoflagellates and bacteria in this treatment on Day 7, and may thus have been a result of DON uptake by these organisms. Although variation was high, the mean bioavailability estimated (DON used/DON added) for the LDOM treatment was $31( \pm 21) \%$, corresponding well with riverine DON bioavailability reported from Northern Europe (Stepanauskas et al. 2002) and elsewhere (Wiegner et al. 2006).

DOM molecule size had a profound effect on the growth of dinoflagellates, but not on the diatoms, although DOM additions did stimulate diatom biomass to some degree. Diatoms and dinoflagellates are 2 important phytoplankton groups in temperate marine ecosystems, and it is thus possible that DOM molecular size may be a factor influencing the taxonomic composition of phytoplankton. Indeed, DOM from humic rivers has earlier been suggested to affect phytoplankton community structure by favouring the development of dinoflagellates (e.g. Granéli \& Moreira 1990). A future increase in atmospheric precipitation is expected over Northern Europe, and as a result, runoff is projected to increase between 5 and $24 \%$ in some areas (Andréasson et al. 2004). Both DOM concentrations and DOM molecule size have been reported to increase in rivers at high river discharge (storm-flow) (e.g. Ludwig et al. 1997, Buffam et al. 2001, Li et al. 2005). Thus, considering the outcome of the present study, such a scenario may facilitate a more dinoflagellate dominated plankton community in estuaries and marine coastal waters in the future. This may have consequences for both marine food webs and ocean-atmosphere $\mathrm{CO}_{2}$ dynamics, since diatoms contribute to an estimated $40 \%$ total oceanic primary production, and as much as $90 \%$ of the photosynthetically produced organic carbon that fuels coastal ecosystems (Nelson et al. 1995). Whether dinoflagellates could complement the nutritional demand of the marine 
ecosystem, should they expand on the expense of diatoms, is unclear. Moreover, a relative higher proportion of toxic species are included among the dinoflagellates and such species may, under the right conditions, form harmful algal blooms that can cause severe negative effects on their grazers (e.g Huntley et al. 1986) and the whole marine food web (see Hay \& Kubanek 2002 for review). Our understanding of how phytoplankton communities are affected by input of terrestrial organic matter, and how this in turn affects estuarine and coastal marine ecosystems is limited. Given the potential effects on both ocean-atmosphere interaction, as well as marine food webs, this subject deserves more attention in the near future.

\section{CONCLUSIONS}

This study suggests that additions of river DOM can stimulate both phytoplankton and bacteria in estuarine/coastal waters, and that large DOM molecules increase dinoflagellate and bacterial growth. These findings correspond well with the DOM-size reactivity concept proposed by Amon \& Benner (1996) that suggests higher bioreactivity of large DOM molecules. Since the experiment was conducted under nitrogen limiting conditions, and DIN concentrations were low, we suggest that DON was used to some extent to support plankton growth. This argument is supported by the observed elevated aminopeptidase activities in the large DOM molecular size treatments where bacteria and dinoflagellates grew well. However, since reductions in DON concentrations were not significantly more pronounced in the large DOM treatments, this remains to be confirmed.

Acknowledgements. We thank Dr. S. Hylander for valuable input and discussions during the preparation of the manuscript, and the staff at Sven Loven Center for Marine Sciences for their help with setting up the experiment. The study was made possible through generous support from the Swedish Research Council for Environment, Agricultural Sciences and Spatial Planning (FORMAS), Helge Ax:son Johnsons foundation, and Axel Persson Bramstorps stipend fund.

\section{LITERATURE CITED}

Amon RMW, Benner R (1996) Bacterial utilization of different size classes of dissolved organic matter. Limnol Oceanogr 41:41-51

Andréasson J, Bergström S, Carlsson B, Phil Graham L, Lindström G (2004) Hydrological Change: climate change impact simulations for Sweden. Ambio 33:228-234

> Azam F, Fenchel T, Field JG, Gray LS, Meyer-Reil LA, Thingstad F (1983) The ecological role of watercolumn microbes in the sea. Mar Ecol Prog Ser 10:257-263
Azúa I, Unanue M, Ayo BL, Artolozaga L, Arrieta JM, Iriberri $J$ (2003) Influence of organic matter quality in the cleavage of polymers by marine bacterial communities. J Plankton Res 25:1451-1460

- Berman T, Bronk DA (2003) Dissolved organic nitrogen: a dynamic participant in aquatic ecosystems. Aquat Microb Ecol 31:279-305

Boyer JN, Dailey SK, Gibson PJ, Rogers MT, Mir-Gonzalez D (2006) The role of dissolved organic matter bioavailability in promoting phytoplankton blooms in Florida Bay. Hydrobiologia 569:71-85

Buffam I, Galloway JN, Blum LK, McGlathery KJ (2001) A stormflow/baseflow comparison of dissolved organic matter concentrations and bioavailability in an Appalachian stream. Biogeochemistry 53:269-306

Butler EI, Knox S, Liddicoat MI (1979) The relationship between inorganic and organic nutrients in sea water. $\mathrm{J}$ Mar Biol Assoc UK 59:239-250

Carlsson P, Granéli E, Tester P, Boni L (1995) Influences of riverine humic substances on bacteria, protozoa, phytoplankton and copepods in a coastal plankton community. Mar Ecol Prog Ser 127:213-221

> Carlsson P, Edling H, Bechemin C (1998) Interactions between a marine dinoflagellate (Alexandrium catenella) and a bacterial community utilizing riverine humic substances. Aquat Microb Ecol 16:65-80

Carpenter SR, Cole JJ, Kitchell JF, Pace ML (1998) Impact of dissolved organic carbon, phosphorous, and grazing on phytoplankton biomass and production in experimental lakes. Limnol Oceanogr 43:73-80

Chen CC, Petersen JE, Kemp WM (1997) Spatial and temporal scaling of periphyton growth on walls of estuarine mesocosms. Mar Ecol Prog Ser 155:1-15

Chróst RJ (1991) Environmental control of the synthesis and activity of aquatic microbial ectoenzymes. In: Chróst RJ (ed) Microbial enzymes in aquatic environments. Springer, New York, NY, p 29-59

Dafner EV, Mallin MA, Souza JJ, Wells HA, Parsons DC (2007) Nitrogen and phosphorus species in the coastal and shelf waters of Southeastern North Carolina, Mid-Atlantic U.S. coast. Mar Chem 103:289-303

Dyhrman S (2005) Ectoenzymes in Prorocentrum minimum. Harmful Algae 4:619-627

Erlandsson M, Buffam I, Folster J, Laudon H, Temnerud J, Weyhenmeyer GA, Bishop K (2008) Thirty-five years of synchrony in the organic matter concentrations of Swedish rivers explained by variation in flow and sulphate. Glob Change Biol 14:1191-1198

Evans CD, Freeman C, Cork LG, Thomas DN, Reynolds B, Billet MF, Garnett MH, Norris D (2007) Evidence against recent climate-induced destabilisation of soil carbon from ${ }^{14} \mathrm{C}$ analysis of riverine dissolved organic matter. Geophys Res Lett 34:L07407, doi:10.1029/2007GL029431

$>$ Fagerberg T, Carlsson P, Lundgren M (2009) A large molecular size fraction of riverine high molecular weight dissolved organic matter (HMW DOM) stimulates growth of the harmful dinoflagellate Alexandrium minutum. Harmful Algae 8:823-831

> Freeman C, Evans CD, Moneith DT (2001) Export of organic carbon from peat soils. Nature 412:785

Gaas BM, Ammerman JW (2007) Automated high resolution ectoenzyme measurements: instrument development and deployment in three trophic regimes. Limnol Oceanogr Methods 5:463-473

Granéli E, Moreira M (1990) Effects of river water of different origin on the growth of marine dinoflagellates and diatoms in laboratory cultures. J Exp Mar Biol Ecol 136: 89-106 
Guillard RRL, Ryther JH (1962) Studies of marine planktonic diatoms. I. Cyclotella 668 Nana Hustedt and Detonula confervacea Cleve. Can J Microbiol 8:229-239

Hay ME, Kubanek J (2002) Community and ecosystem level consequences of chemical cues in the plankton. J Chem Ecol 28:2001-2016

Hejzlar J, Dubrovsky M, Buchtele J, Ruzicka M (2003) The apparent and potential effects of climate change on the inferred concentration of dissolved organic matter in a temperate stream (the Malse River, South Bohemia). Sci Total Environ 310:143-152

> Hongve D, Riise G, Kristiansen JF (2004) Increased colour and organic acid concentrations in Norwegian forest lakes and drinking water: a result of increased precipitation? Aquat Sci 66:231-238

> Hoppe HG (1983) Significance of exoenzymatic activities in the ecology of brackish water: measurements by means of methylumbelliferylsubstrates. Mar Ecol Prog Ser 11: 299-308

> Huntley ME, Sykes P, Rohan S, Marin V (1986) Chemically mediated rejection of dinoflagellate prey by the copepods Calanus pacificus and Paracalanus parvus: mechanisms, occurrences, and significance. Mar Ecol Prog Ser 28: 105-120

Klut ME, Bisalputra T, Antia NJ (1987) Some observations on the structure and function of the dinoflagellate pusule. Can J Bot 65:736-744

Kullberg A, Petersen RCJ (1987) Dissolved organic carbon, seston and macroinvertebrate drift in an acidified and limed humic stream. Freshw Biol 17:553-564

Legrand C, Carlsson P (1998) Uptake of high molecular weight dextran by the dinoflagellate Alexandrium catenella. Aquat Microb Ecol 16:81-86

Li F, Yuasa A, Muraki Y, Matsui Y (2005) Impacts of heavy storms of rain upon dissolved and particulate organic C:N and $\mathrm{P}$ in the main river of a vegetation-rich basin in Japan. Sci Total Environ 345:99-113

Ludwig U, Neumann V, Grischek T, Nestrler W (1997) Application of ultrafiltration for characterization of the DOC of Elbe river water. Acta Hydrochim Hydrobiol 25:71-78

Nelson DM, Tréguer P, Brzezinski MA, Leynaert A, Quéguiner B (1995) Production and dissolution of biogenic silica in the ocean: revised global estimates, comparison with regional data and relationship to biogenic sedimenta-

Editorial responsibility: Graham Savidge,

Portaferry, UK tion. Global Biogeochem Cycles 9:359-372

Porter KG, Feig YS (1980) The use of DAPI for identifying and counting aquatic microflora. Limnol Oceanogr 25:943-948

Richardson K, Beardall J, Raven JA (1983) Adaptation of unicellular algae to irradiance: an analysis of strategies. New Phytol 93:157-191

Salerno M, Stoecker DK (2009) Ectocellular glucosidase and peptidase activity of the mixotrophic dinoflagellate Prorocentrum minimum (Dinophyceae). J Phycol 45:34-45

See JH, Bronk DA, Levitus AJ (2006) Uptake of Spartinaderived humic nitrogen by estuarine phytoplankton in nonaxenic and axenic culture. Limnol Oceanogr 51: 2290-2299

Seitzinger SP, Sanders RW, Styles R (2002) Bioavailability of DON from natural and anthropogenic sources to estuarine plankton. Limnol Oceanogr 47:353-366

Stepanauskas R, Jørgensen NOG, Eigaard OR, Zvikas A, Tranvik LJ, Leonardson L (2002) Summer inputs of riverine nutrients to the Baltic Sea: bioavailability and eutrophication relevance. Ecol Monogr 72:579-597

Stoecker DK (1999) Mixotrophy among dinoflagellates. J Eukaryot Microbiol 46:397-401

> Stoecker DK, Gustafson DE Jr (2003) Cell surface proteolytic activity of photosynthetic dinoflagellates. Aquat Microb Ecol 30:175-183

Stolte W, Balode M, Carlsson P, Grzebyk D and others (2006) Stimulation of nitrogen-fixing cyanobacteria in a Baltic Sea plankton community by land-derived organic matter or iron addition. Mar Ecol Prog Ser 327:71-82

Tulonen T, Salonen K, Arvola L (1992) Effects of different molecular weight fractions of dissolved organic matter on the growth of bacteria, algae and protozoa from a highly humic lake. Hydrobiologia 229:239-252

Vuorenmaa J, Forsius M, Mannio J (2006) Increasing trends of total organic carbon concentrations in small forest lakes in Finland from 1987 to 2003. Sci Total Environ 365:47-65

Wiegner TN, Seitzinger SP (2004) Seasonal bioavailability of dissolved organic carbon and nitrogen from pristine and polluted freshwater wetlands. Limnol Oceanogr 49: 1703-1712

Wiegner TN, Seitzinger SP, Glibert PM, Bronk DA (2006) Bioavailability of dissolved organic nitrogen and carbon from nine rivers in the eastern United States. Aquat Microb Ecol 43:277-287

Submitted: July 3, 2009; Accepted: April 9, 2010

Proofs received from author(s): June 9, 2010 